has to be designed so that it is in keeping with the older equipment. A large reserve of the old equipment has to be maintained to meet the changing traffic demands made on it. Some engineers are afraid that there may be a public reaction after the very pleasant boon which the railways afforded when streamlined trains were first used. There is evidence of dissatisfaction when the public learns that a 100-120 miles an hour train is placed in revenue service on a 50-60 miles an hour schedule. Even although the maximum speed has been attained en route, the public feels that it has been misled.

\section{Agricultural Research Institutes in Great Britain}

THE Ministry of Agriculture has now published the report of the work of the agricultural research institutes in the United Kingdom for 1933-34 (London : H.M. Stationery Office; $5 s$. net). Besides describing the investigations carried out at the fortyfour principal institutes, the report deals with the work at various advisory centres and special Stateaided researches carried out in different parts of the country. The problems concerned cover a wide field, including soils, plant nutrition, physiology, breeding and disease, dairying, animal nutrition, breeding, diseases and pests, food preservation and transport, and agricultural engineering. Should anyone desire further information, a list of papers published from each centre is supplied so that reference to the original source of the work is available, and inquiries may also be addressed to the director of the institute or person concerned, the names and addresses of whom are listed.

\section{The American Amaryllis Year Book}

The American Amaryllis Society has issued vol. 2, its Year Book for 1935 (from the Editor, Dr. Hamilton P. Traub, Mira Flores, Orlando, Florida, U.S.A.). It is dedicated to Theodore L. Mead, in recognition of his pioneer work with hybrid Hippeastrum plants. Gardeners are familiar with narcissi, they bestow a rather occasional interest upon day lilies (Hemerocallis spp.), they cultivate Alstromeria; but most horticulturalists have not yet realized the wonderful beauty displayed by the new hybrids of Hippeastrum. The Society has an international outlook, for a large part of the volume is devoted to regional activities in Australia, Kenya, Europe, and all parts of America. A section on "Description and Phylogeny" quotes inter alia from Dr. J. Hutchinson's recently published volume on the classification of monocotyledons. Robert F. Ruthruff contributes a paper describing the alkaloids found in various Amaryllidaceæ, and the late Dr. David Griffiths directs attention to "Opportunities for Breeding with Daffodils". Two valuable papers by Miss Ida Luyten and Dr. Traub introduce new methods of vegetative propagation of amaryllids. Fifteen papers deal with culture, five with curing, storage and forcing, and a similar number with marketing. The editor has introduced the idea of quoting one or two abstracts from scientific papers relevant to Amaryllis culture, and though the index shows nearly sixty papers, no subject appears to have inadequate treatment. Plans have already been made for publishing year books so far ahead as 1938 ; the Society occupies a position of great utility and high æsthetic value.

\section{Early Photographs}

THE June issue of the Alumnus Chronicle of the University of St. Andrews contains an article by $\mathrm{Mr}$. J. H. Read describing a collection of prints by early photographers which illustrate the local development of the art and have been presented to the University by Mr. James Thomson of Inverness. The oldest photographs of the collection are of buildings in St. Andrews produced by the Calotype process about the year 1840. Portraits of St. Andrews worthies, for example, Sir Lyon Playfair and Sir David Brewster, by the process date from about 1850. The majority of the photographs are albumen prints from wet collodium plates taken during the next twenty years, and include portraits, scenery and reproductions of pictures. The article is illustrated by reproductions from paper negatives by Thomas Rodger of a St. Andrews fishing quarter in 1843 , and a portrait of Prof. George Day, professor of medicine, 1850, both of which are remarkably good.

\section{Films and their Utilization}

THe current number of Film Progress is in two parts. It contains the usual supplementary bulletin to the National Encyclopædia of Films. In this section are noted a good number of films, both $35 \mathrm{~mm}$. and $16 \mathrm{~mm}$., of G. B. Equipments and Pathé. Silent films of Ensign and C.I.B.E.F. are also listed. The other section deals mainly with the educational value of the sound film. This is in effect a résumé of the arguments put forward by C. F. Hoban in a symposium on "Sound and Silent Films" held at the University of Chicago. The arguments are well stated, but the article reads too much like special pleading, seeing that the arguments for the silent film presented to the symposium are not mentioned. We hope that they will be stated in a future number.

\section{Third World Power Conference}

THE following official delegates have been appointed to represent the Government of the United Kingdom at the Third World Power Conference and Second Congress, International Commission on Large Dams of the World Power Conference, to be held coneurrently in Washington, D.C., on September 7-12 : Viscount Falmouth, Mr. N. G. Gedye, Mr. T. Hardie, Mr. J. M. Kennedy, Dr. F. M. Lea, Mr. Charles H. Merz, Sir Archibald Page, Mr. C. Rodgers, Dr. F. S. Sinnatt and Mr. E. T. Williams. The final time-table for the Conference has now been announced. The joint opening session will be held in Constitution Hall, Washington, on Monday, September 7, at 8.30 p.m. Business sessions will be held earlier on the same day and throughout the week. There will be an address by the President of the United States on September 11 at 2 p.m. followed by a garden party and reception at the White House. 